\title{
Top-down, bottom-up or outside-in? An examination of triadic mechanisms on firm innovation in Chinese firms
}

\section{Yu Zhou ${ }^{1} \cdot$ Guangjian Liu ${ }^{1} \cdot$ Xiaoxi Chang ${ }^{2} \cdot$ Ying Hong $^{3}$}

Received: 16 April 2019 / Revised: 19 July 2019 / Accepted: 29 August 2019 /

Published online: 14 September 2019

(C) The Author(s) 2019

\begin{abstract}
This paper examines the influence of the interaction of three sources of innovation, namely, top-down (bureaucratic structure), bottom-up (high-involvement HRM) and outside-in (outreaching network), on two stages of firm innovation, i.e. invention and commercialization. Using data from 620 large Chinese companies, we found that there was a synergy between the bureaucratic structure and a high-involvement HRM system in influencing firm innovation. Social networks were most effective in promoting firm innovation in the presence of a high-involvement HRM system. The bureaucratic structure inhibited social networks in contributing to firm innovation. Ideas for future research and practical implications are discussed.
\end{abstract}

Keywords Bureaucracy · High involvement · Social network · Firm innovation · China

Yu Zhou

zhouyuhr@ruc.edu.cn

$\bowtie$ Xiaoxi Chang

cecilia.chang@foxmail.com

Guangjian Liu

lgj19890622@126.com

Ying Hong

yhong24@fordham.edu

1 School of Business, Renmin University of China, No. 59 Zhongguancun Street, Haidian District, Beijing 100872, China

2 School of Business, China University of Political Science and Law, No. 27 Fuxue Road, Changping Dist., Beijing 102249, China

3 Gabelli School of Business, Fordham University, 140 W. 62nd Street, Room 301, New York, NY 10023, USA 


\section{Introduction}

Innovation is crucial for today's organizations to create and sustain competitive advantages (Brem et al. 2016; Herrera 2015; He et al. 2019; Huang et al. 2016; Rialp-Criado and Komochkova 2017). Micro and macro studies alike have sought to identify the determinants of firm innovation (Ahuja et al. 2008; Crossan and Apaydin 2010; Jing et al. 2017; Luong et al. 2017; Rothaermel and Hess 2007; Zhou et al. 2019), which range from structural characteristics (Damanpour 1991; Damanpour and Aravind 2011; Jia et al. 2019) to human capital and social networks (Ahuja 2000; Bornay-Barrachina et al. 2016; Yang and Shafi 2019; Subramaniam and Youndt 2005; Zhang et al. 2017). A recent constructive review of the cumulated literature on innovation, however, suggests that despite the multi-level, multi-facet, and complex nature of innovation, each study has tended to adopt a one-dimensional definition of innovation, tackle innovation from a single level of conceptualization and use variables from one sub-field of research, which present a vastly heterogeneous and fragmented picture of innovation (Anderson et al. 2014). Hence, many precious opportunities for future innovation research exist, which we will delineate below.

First, in a review of extant conceptualizations of innovation, Anderson et al. (2014) called for "more radical conceptualizations of creativity and innovation processes and outcomes" (p. 1318). The prior research has suggested that there are two stages of innovation, namely, the invention stage and the commercialization stage. To distinguish among the terminologies of innovation, we use invention to refer to the first stage of innovation (Hansen and Wakonen 1997), which was also called "creativity and innovation" by Anderson et al. (2014) and defined as "the process, outcomes, and products of attempts to develop and introduce new and improved ways of doing things" (p. 1298). It should be noted that our definition of invention encompasses both the generation of ideas (creativity) and the conversion of these ideas into new ways of doing things (implementation) (Anderson et al. 2014; Baer 2012). Examples are intellectual properties or new products. We call the second stage of innovation "commercialization", which relates to the diffusion of innovation (Hansen and Wakonen 1997) or "the sales and profits retrieved from new products and services" (Mueller et al. 2013, p. 1613). Examples include the new products that are successfully brought to market and the revenue generated from such products.

Although there is little doubt that invention is critical for organizations to become competitive (which is the focus of most previous studies), is invention sufficient for organizations to create competitive advantage? This question is meaningful because coming up with new inventions does not always lead to successful products and value creation for an organization (James et al. 2013; Mueller et al. 2013). Thus, in addition to understanding the factors predicting organizations' abilities to invent, to obtain a more comprehensive understanding of innovation, it is equally important to investigate the elements that can help organizations successfully bring new products to market and generate revenue from such products. However, existing research on the second stage of innovation is lacking (Anderson et al. 2014). 
Second, Anderson et al. (2014) suggested that one of the most valuable venues for future research is to propose "models and theoretical propositions to explain crosslevel and multilevel innovation" (p. 1318). If the sources of innovation are derived at the individual, organizational and network levels in reality, focusing on only one level of antecedents and assuming that all other level factors are homogeneous will inevitably result in spurious findings (Rothaermel and Hess 2007). We thus conceptualize multi-level sources of innovation, all of which are directly managed by the organization and have important practical implications, in one integrated model. As an individual-level source of innovation, employees or human resources (HR) have been considered one of the most important carriers of firm intellectual capital and sources of firm innovative capabilities (Kang and Snell 2009; Kianto et al. 2017; Soo et al. 2017; Subramaniam and Youndt 2005). The present research has suggested that individual motivation, task contexts, and leader and co-worker influences are critical factors that determine individual innovation performance (Anderson et al. 2014). All of these factors can be effectively managed using a high-involvement HRM system, which includes management practices that focus on involving employees in knowledge sharing, management participation and decision making (Boxall and Macky 2009). We focus on high-involvement HRM systems because they develop innovative human capital; motivate employees to absorb, transfer, share and create knowledge; and provide opportunities for employees to invent and commercialize innovation (Beugelsdijk 2008; Li et al. 2018b; Shipton et al. 2006). With high-involvement HRM systems, organizational innovation is promoted from the bottom-up by unleashing the innovative capabilities of its employees.

As an organizational source of innovation, the organizational structure also shows a decisive impact on firm innovation outcomes (Anderson et al. 2014). The bureaucratic structure, featuring centralized decision making and formalized processes, is one of the key factors that has been thought to impede innovation (Hlavacek and Thompson 1973; Thompson 1967). This assumption, however, deserves further investigation because some researchers have suggested that bureaucracy may have different effects on different types of innovation (Jansen et al. 2006). Bureaucracy may be helpful, for example, for organizations to engage in top-down strategic renewal or implement predetermined innovation goals (Poskela and Martinsuo 2009).

In addition to individual and organizational sources of innovation, innovation can also be generated at the social network level (Guan et al. 2015; Powell et al. 1996; Zahra and George 2002). Given the increasing complexity and dynamism in the process of regenerating knowledge, it is difficult for any single organization to possess all necessary knowledge and capacities to innovate (Ahuja et al. 2008). It is therefore imperative that social networks be taken into account when investigating innovation processes from the outside-in. We therefore included all three levels of innovation sources in an integrated model.

Third, Anderson et al. (2014) welcomed "studies that set up empirically testable hypotheses based upon interactions between multiple variables" (p. 1318). Studies that have focused on a focal antecedent to innovation while assuming that the effects are largely independent of other factors that operate simultaneously have inexorably generated spurious findings (Rothaermel and Hess 2007). The prior research 
has suggested that the effect of bureaucracy on innovation varies based on contingencies, such as organizational size and industrial sectors (Damanpour 1996). Furthermore, recent research has examined bureaucracy as a moderating variable in the relationships between team goal orientation and creativity (Hirst et al. 2011) and between team empowerment and team innovation (Hempel et al. 2012). The bureaucratic structure thus may have differential effects on innovation outcomes under different contingencies. Similarly, HR practices may interact with internal structural and external contextual variables (Jackson and Schuler 1995; Shalley et al. 2004), and social network-based innovation is often contingent on the capacity to absorb knowledge from outside networks (Vanhaverbeke et al. 2009). Therefore, examining one source of innovation independently may present a partial picture of innovation at best.

The present study contributes to the existing literature in three ways. First, although innovation can be derived from the "bottom-up", "top-down" and "outsidein" perspectives, the majority of existing studies tend to focus on only one perspective (Mom et al. 2007; Rothaermel and Hess 2007). By integrating the prior research stemming from different fields, we view the sources of innovation from a multi-level perspective, which can help to foster a comprehensive understanding of the influencing factors of innovation. Second, this study contributes to the boundary conditions (i.e. firm ownership style) of the effect of the bureaucratic structure, high-involvement HRM system and social network through split-sample analysis. Although most studies tend to pay attention to the positive effect of high-involvement HRM systems and social networks and the negative effect of bureaucratic structures, our study contributes to these studies by demonstrating that their effects are quite complicated and depend on boundary conditions, such as a firm's ownership style. Third, by synthesizing three interdisciplinary perspectives from top authority-driven, employeedriven and network-driven perspectives, we find that the interactive effects of these different perspectives can be combined with each other to exert a complementary influence on firm innovation, which deepens our knowledge of the complex and interactive mechanisms of the influencing factors of firm innovation.

\section{Theory and hypotheses}

Innovation is a multi-phase and multi-level construct (Sears and Baba 2011). The central tenet of innovation research is its "novelty" and "value-addedness", as initially suggested by Schumpeter (Crossan and Apaydin 2010). Based on this notion, we adopt a comprehensive definition of innovation that considers both phasesinvention and commercialization-of innovation. Invention involves exploring new products for emerging customers, while commercialization involves exploiting these products for profit generation, which may involve other production and administrative functions (Crossan and Apaydin 2010; Damanpour 1991).

Aside from its multi-phase nature, innovation is also simultaneously fuelled by factors spanning multiple levels of the organization (Anderson et al. 2014). Below, we synthesize the innovation research generated in three different sub-fields of study, namely, organizational structure, human resource management and social 
networks. These represent three different levels of sources by which innovation is stimulated: the organizational structure orchestrates the process of innovation from the "top-down"; high-involvement HRM systems inspire individual creativity from the "bottom-up"; and social networks complement the prior two levels by bringing resources from the "outside-in". Together, the three levels constitute a comprehensive model of the antecedents of innovation.

\section{Bureaucratic structure: orchestrating innovation from the "top-down"}

The bureaucratic structure can be understood in terms of two primary dimensions: centralization and formalization (Bolin and Härenstam 2008; Knight et al. 2018). Centralization refers to the extent to which power is distributed according to the organizational hierarchy, and decisions are made from the top-down (Damanpour 1991; Hage and Aiken 1967). Formalization pertains to whether there are explicit specifications for the procedures and regulations that govern individual behaviours and activities (Pugh et al. 1963). Centralization and formalization were traditionally thought to hinder innovation processes and outcomes (e.g. Li et al. 2018a). Centralization reduces opportunities to express ideas and explore alternative solutions (Keum and See 2017; March and Simon 1958) and suppresses individuals' learning orientation (Hirst et al. 2011). Similarly, formalization creates a coercive mechanism that suffocates the openness with which employees can freely contribute new ideas and engage in new behaviours (Adler and Borys 1996; Eva et al. 2017; Pierce and Delbecq 1977).

The coercion brought about by centralization and the rigidity embedded in a formalized structure not only restrain the generation of innovative ideas (Jansen et al. 2006) but also inhibit the processes through which innovative outcomes are commercialized. Hierarchical organizations tend to self-reinforce the existing power structure (Magee and Galinsky 2008), which may intensify the barriers between divisions and hinder cross-functional collaboration. As such, the manufacturing or distribution of new products may encounter difficulty if the different divisions responsible for different components or tasks could not come to an integrated solution responsively, thereby deterring the commercialization of innovative outcomes. Research has shown that centralization and formalization negatively influence the technological and managerial innovation of organizations and units, as well as bottom-line innovative performance (Damanpour 1991; Jansen et al. 2006).

\section{High-Involvement HRM system: inspiring innovation from the "bottom-up"}

Whereas the bureaucratic structure pertains to a holistic organizational design, high-involvement HRM systems create an empowering climate through practices such as information sharing, employee suggestions, self-management teams, crossfunctional teams and job rotations. The intention is to obtain the most autonomous and creative human capital, unleash the creativity of most "ordinary" employees, and manage the chemistry among diverse types of human capital to generate innovation from the bottom-up (Schneider et al. 2000). Additionally, high-involvement 
practices provide support for employees in fully exploiting their specific human capital (expertise/exclusive knowledge), independent of new methods to improve work performance (Shin et al. 2016), being intrinsically motivated to accomplish higher goals, and helping organizations achieve higher levels of innovation through employee suggestions (De Dreu and West 2001).

Aside from unleashing the creativity of employees, to commercialize new products, organizations need to possess advanced manufacturing capabilities, an important competency that is also derived from internal HR (Zahra and Nielsen 2002). High-involvement HRM practices that encourage multi-skilling, job rotations, cross-functional teamwork and information sharing convey value for human capital versatility, managerial flexibility and interdependent cooperation (Bhattacharya et al. 2005; Martínez-Sánchez et al. 2011). These, in turn, will facilitate the sharing of technological and market information, the accumulation of internal financial and social capital, and the integration of technological and commercial processes, thereby accomplishing the translation of innovative products into commercialized applications (Kang and Snell 2009; Maurer et al. 2011).

\section{Social network: bringing innovation from "outside-in"}

As knowledge and resources tend to be limited and homogeneous within groups and organizations, having connections with external sources is imperative for gaining access to diverse and novel ways of thinking (Burt 2004; Howard et al. 2016). Nambisan and Sawhney (2011) suggested that firms have gradually shifted away from "firm-centric innovation" to "network-centric innovation". The macroeconomic research has raised the concept of the "national/regional innovation system", in which organizations establish an interacting network with industrial partners, financial institutions, educational and research institutions, consulting companies and government organizations to effectively realize knowledge spillover, technology diffusion, and organizational and industrial innovation (Cooke and Morgan 1998; Lundvall 1992).

Collaborations with external networks transfer know-how and assets across firms, as well as provide access to knowledge spillover, where new insights and information flow across firms (Ahuja 2000). Social networks help organizations extend their internal resources by acquiring a variety of innovative resources that are otherwise unavailable in the market (Gulati 1999; Phelps 2010). Horizontal connections with academic and research institutions, consulting firms, and other knowledge-intensive institutions allow organizations to have access to resources that represent the industry's most cutting-edge research and best practices. Vertical connections with suppliers often create knowledge "spill over" that helps downstream organizations reduce their R\&D costs and improve their product quality (Harhoff 1996), which directly contribute to the innovation outcomes of downstream organizations. As invention relates to coming up with new solutions for emerging customers, customer input and customer affective-based trust are particularly conducive to service-related creativity (Madigan and Hoover 1986). Especially in a dynamic environment, a strategic alliance helps improve the efficiency of knowledge exchange and transfer and 
develop a mechanism to continuously assimilate tacit, routine-embedded knowledge for technological renewal and exploratory innovativeness (Teece 1992).

In addition, having network connections can be conducive to promptly bringing new products to market (Oxley and Sampson 2004). For example, connections with suppliers and customers can provide useful information about the opportunities and threats that exist in the market (Uzzi 1997), which helps firms discern customers' needs and thus properly position their products to reap the business benefits of innovation (Christensen and Bower 1996). Zahra and Nielsen (2002) found that external alliances and joint ventures, outsourcing and licensing, and other external human capital are positively associated with the speed of technological commercialization.

While these aforementioned mechanisms have often been studied separately, they may also interact with each other to influence invention and commercialization. The investigation of their interactions, however, would not be possible without including all three in an integrated model.

\section{Bureaucratic structure and high-involvement HRM interaction}

Although the bureaucratic structure conveys a "top-down" philosophy, whereas a high-involvement system represents "bottom-up" thinking, the two are not mutually exclusive; in fact, they may complement each other in determining firm innovative performance. The bureaucratic structure and inherent centralized decision making and formalized management procedures have demonstrated effects on organizational stability, norms and operating efficiency (Magee and Galinsky 2008; ZakrzewskaBielawska 2016). Innovative organizations distinguish themselves from other coercive bureaucratic organizations by supplementing the bureaucratic system with a management system that informs employees of the rationale behind the rules and regulations, facilitates employees' initiative taking to solve emerging problems and allows for flexibility in the implementation and improvement of procedures (Adler and Borys 1996). For example, GE introduced the reputational "Work-Out" programme to overcome organizational bureaucracy by bringing together employees and managers from different levels and functions of the organization to tackle problems in unconventional ways. This programme has been very successful in reducing the bureaucratic barriers and processing times at GE (Ulrich et al. 2002).

Bureaucratic structures can provide a clear direction for collective efforts and optimize resource allocation for innovation, while high-involvement HRM systems can help stimulate individuals' creativity and initiative taking (Kesting and Ulhøi 2010), both of which can work in tandem to enhance the invention and commercialization of innovation. Centralized decision making and resource allocation ensure that appropriate investments are planned for innovation, which is particularly important for high-risk, radical or exploratory innovation (Ettlie et al. 1984). The recent research has shown that formalized procedures can enhance team self-management and empowerment by providing proper guidance and boundaries (Hempel et al. 2012), improve team learning by augmenting employees' psychological safety and reducing conflicts (Bunderson and Boumgarden 2010), and stimulate individual 
creativity by encouraging more individual devotion and practice (Gilson et al. 2005), all of which will greatly contribute to invention.

The synergy between bureaucracy and high-involvement HRM systems is also conducive to facilitating the commercialization of innovation. The translation of individual creativity and initiative taking into organizational innovative capabilities requires formalized goals and procedures to guide individual behaviours and to avoid chaotic individual endeavours (Hirst et al. 2011; Mintzberg 1979). As the commercialization of innovation requires an integrated and interdependent manufacturing and distribution process, it is particularly important that organizations possess a strong structure to accelerate such a process (Smith and Tushman 2005). Therefore, we propose a positive interaction of both bureaucracy and high-involvement HRM systems with invention and commercialization.

Hypothesis 1a When there is a bureaucratic structure, a high-involvement HRM system will be more positively related to invention than when there is an organic structure.

Hypothesis 1b When there is a bureaucratic structure, a high-involvement HRM system will be more positively related to commercialization than when there is an organic structure.

\section{High involvement and social network interaction}

As discussed above, a critical condition for firms to utilize resources from external social networks is that firms possess the ability to leverage the external network and to absorb network resources (Eisenhardt and Martin 2000; Teece et al. 1997). We argue that organizations with endogenous high-involvement HRM systems can better absorb and translate external resources for internal use in the invention process. Practices such as teamwork and rotations facilitate the identification and connection of network resources, whereas practices including information sharing, joint problem-solving, knowledge exchange and combination, and so forth contribute to the retrieval and absorption of network resources (Maurer et al. 2011). Therefore, having a high-involvement HRM system can facilitate the mobilization and assimilation of resources across organizational boundaries.

Specifically, the synergy between high-involvement HRM systems and social networks will contribute to both the invention and commercialization stages of innovation. The knowledge and abilities developed by a high-involvement HRM system assist the organization in growing the acumen for choosing the most innovative partners with which to collaborate. Enhanced human capital can also supplement and extend the capabilities of social connections to develop radically innovative solutions. Indeed, Subramaniam and Youndt (2005) showed that organizational human capital interacts with social capital to enhance radical innovation outcomes. In a high-involvement HRM system featuring teamwork and job rotations, employees develop a breadth of knowledge on both technical and managerial exposure, which serve as common communication protocols with which the organization can 
effectively collaborate with external connections. Such a breadth of knowledge enables employees to assimilate external knowledge for innovation (Kijkuit and van den Ende 2007). This is in accordance with Zahra and Nielsen's (2002) finding that high involvement is positively integrated with external strategic alliances and joint ventures to determine the number of new products, the number of radically new products and the number of patents of organizations.

High-involvement HRM systems also create a culture of high empowerment and job enrichment, which offers greater flexibility and more opportunities for employees to utilize internal and external resources to establish connections for quickly and successfully bringing new products to market. With high-involvement HRM systems, organizations can develop more and stronger ties across functions, business units and partners (Kang et al. 2007), which are conducive to collaborating with external alliances to efficiently produce and distribute new products. This concurs with Zahra and Nielsen's (2002) finding that integration across functions, operationalized as formal coordination and involvement, positively interacts with alliances and joint ventures to influence the speed of technological commercialization. Based on these findings, we propose that a high-involvement HRM system is important for firms to utilize resources from external social networks for innovation.

Hypothesis 2a When there is a high-involvement HRM system, an outreaching social network will be more positively related to invention than when there is a lowinvolvement HRM system.

Hypothesis 2b When there is a high-involvement HRM system, an outreaching social network will be more positively related to commercialization than when there is a low-involvement HRM system.

\section{Bureaucratic structure and outreaching social network interaction}

Given the scarcity of studies that investigate the interaction effect of the bureaucratic structure and social networks, we propose the hypotheses for both a positive interaction and a negative interaction in a competing fashion.

On the one hand, there are reasons to expect that the bureaucratic structure can facilitate organizations' utilization of social networks for innovation. The extent to which firms can exploit external knowledge depends not only on their ability to leverage the network but also on their ability to reduce the protectiveness within organizations (Lichtenthaler et al. 2010). To overcome internal protectiveness, firms need to establish a formal organizational mechanism that creates clear communication channels and standardized routines to ignite the collaboration efforts of network members and to facilitate the digestion and diffusion of external knowledge for innovation (Kijkuit and van den Ende 2007). In the previous research, structural formalization was found to positively influence the transformation and exploitation of external knowledge (Jansen et al. 2005; Lin and Germain 2003). Recent theories further suggest that, as a form of mechanistic organizational capital, bureaucracy helps to establish organizational cooperative social capital and provide clear decision rules 
to facilitate in-depth knowledge exchange and architectural knowledge integration, thereby enhancing the exploitative learning of organizations. The formalized procedures provide a clear direction for entrepreneurial social capital to converge, avoiding the formation of chaotic social connections and offering the latitude and discretion needed for achieving explorative innovation (Kang and Snell 2009).

Aside from removing internal protectiveness for network-based invention, an effective bureaucracy also helps organizations develop orchestration mechanisms to realize network-centric commercialization. One ideal condition for organizations to distribute new products in a network is that the organization is located in the centre of the network (i.e. as the hub firm), based on which the organization assumes the role of an orchestrator to initiate network design and manage the orchestration processes (Dhanaraj and Parkhe 2006). The focal organization must possess strong and centralized power to reinforce a common identity among network members, to motivate members to share knowledge across boundaries and to assign specific responsibilities to partners for the realization of network-level coordination and integration. Moreover, the focal organization needs formalized procedures to establish polices and guidelines for mutual interaction, thereby ensuring consistency in the decision-making process and procedural justice (Nambisan and Sawhney 2011). All these factors suggest that organizational bureaucracy can facilitate the commercialization of innovation using the network. Zahra and Nielsen (2002) found that formal coordination within organizations accentuates the influence of external alliances and joint ventures on the number of patents, the number of new products, the number of radically new products and the speed of technological commercialization. Therefore, we propose the following:

Hypothesis 3a When there is a bureaucratic structure, the outreaching social network will be more positively related to invention than when there is an organic structure.

Hypothesis $\mathbf{3 b}$ When there is a bureaucratic structure, the outreaching social network will be more positively related to commercialization than when there is an organic structure.

On the other hand, bureaucracy may also hinder an organization's ability to leverage and absorb social network resources for innovation. As Dhanaraj and Parkhe (2006) pointed out, hub firms do not orchestrate network-based innovation activities by utilizing their hierarchical authority. When the internal bureaucratic structure is strong, the organization may over utilize its control over the network members, thereby disturbing the equilibrium established by network members in exchanging knowledge and resources. Similarly, bureaucratic organizations tend to self-reinforce their power structure because individuals with higher power are inclined to possess higher confidence and view other individuals in a more instrumental manner (Magee and Galinsky 2008), and such organizations may also operate beyond the organizational boundary when members interact with external parties and interfere with the exchange mechanisms established in the collaborating networks. 
In addition, the complex and rigid processes embedded in a bureaucratic structure may limit employees' flexibility to deviate from existing routines (Jansen et al. 2006), which is important for making use of the knowledge and resources available in the network for the commercialization of new products. The manufacturing of newly developed products requires the iteration and adaptation of various processes to generate an integrated product; similarly, the distribution of new products also requires flexibility for employees to interact with various parties. Both processes will likely be hindered by a bureaucratic structure. Therefore, we also propose a hypothesis of a negative interaction between bureaucracy and social networks in both stages of innovation:

Hypothesis 4a When there is a bureaucratic structure, the outreaching social network will be less positively related to invention than when there is an organic structure.

Hypothesis 4b When there is a bureaucratic structure, the outreaching social network will be less positively related to commercialization than when there is an organic structure.

\section{Methods}

\section{Sample}

The surveys were administered as part of a nationwide "Independent Innovation Evaluation Project for Chinese Enterprises" survey, conducted by the Development Research Center of The State Council of China (DRCSC) and implemented by China Enterprise Evaluation Association (CEEA) to measure the degree of innovation among Chinese companies. Our sample contains Chinese enterprises with different types of ownership and from different regions. Since this study mainly focuses on enterprises' innovation capability and output, our sample includes specific industries with a higher degree of innovation, such as the IT industry and the environmental protection industry. The number of enterprises included in all these industries is almost equal, and their annual revenue is greater than or equal to 20 million RMB.

As a nationwide survey, the sample comes from a variety of sources. First, through the network information platform exposed by CEEA, enterprises that meet the requirements can register and participate independently and provide their effective contact information. Second, for the listed companies that meet the above sample standards, we collect effective contact information through public information materials, such as annual reports. Third, to ensure the wide coverage of the samples, we obtain the list of recommended enterprises that meet the sample requirements and their contact details from four categories of institutions: the trade association of each industry, the science and technology management departments of local governments, the administrative committee of high-tech development zones, and local commercial and industrial associations. By integrating these sources, we identified 10,000 companies that could be effectively 
linked as the subject of the survey. The research team included more than 50 people and was composed of survey moderators and graduate students. All researchers received no less than four hours of specialized training on the content and methodology of the study.

From April to July 2013, the research personnel directly contacted the sample enterprises by telephone, email, etc., and eventually, surveys with instructions for administration were mailed to the head office of each company. To ensure the accuracy, reliability and confidentiality of data administration, we requested that if the companies have questions, then they should contact the researcher directly to further discuss the administration procedure. All surveys were conducted in Chinese.

To reduce common method bias (Podsakoff et al. 2003), we used multiple data sources. First, we collected archival data on the innovation indicators, which were provided by the finance departments. Second, we employed multiple sources for survey administration: the human resources/personnel administration department head completed the measures on the bureaucratic structure and high-involvement HRM practices, and the CEO/general manager completed the measures on the external social network. We excluded those companies that did not provide archival data on innovation outcomes; such resistance is common among Chinese organizations and has been documented in the prior research (Peng and Luo 2000). We finally had useable data from 620 companies, with a response rate of $6.2 \%$. This is consistent with the average response rate of $6-28 \%$ for studies that have conducted company-level data collection (Becker and Huselid 1998).

Of all responding companies, 45.6\% were state-owned enterprises (SOEs), $27.2 \%$ were foreign-invested enterprises (FIEs) and $27.1 \%$ were private companies. Publicly listed companies represented $59.6 \%$ of the sample. The industry breakdown of the participating organizations was as follows: $19.5 \%$ were in the energy sector, $20.3 \%$ were information technology (IT) companies, $19.2 \%$ were biotechnology companies, $20.3 \%$ were manufacturing companies and $20.8 \%$ were involved in energy saving and environmental protection. The average company size was 14,000 employees ( $\mathrm{Lg}$ company size $=3.48$. $\mathrm{SD}=0.67$ ). The average company age was 18.82 years $(\mathrm{SD}=14.08)$; the average revenue generated in 2009 was 18.06 million $\mathrm{RMB}(\mathrm{SD}=0.96$ million).

\section{Measures}

\section{Firm innovation}

Following prior studies that operationalized innovation as a multi-faceted concept (Zahra and Nielsen 2002), we measured innovation outcomes using four indicators: the number of patents generated, the number of new products developed (NPD), the number of NPD introduced to the market and the revenue generated from the NPD in 2010. The former two indicators represent the firm's generation of new inventions (Narin et al. 1987), while the latter two indicators describe the success of commercializing the innovation (Song and Parry 1996). 


\section{Bureaucratic structure}

We measured the bureaucratic structure in terms of both centralization and formalization (Bolin and Härenstam 2008). We adapted the measures, assessing the extent to which decision making is centralized and clear rules and regulations exist (Damanpour 1996; Hirst et al. 2011; Hlavacek and Thompson 1973). Specific items were "innovation ideas were raised by company management", "innovation projects were initiated by company management", "the organizational structure and procedures were developed by company management", "there were clear rules and regulations guiding various activities" and "the company monitored various work activities via a broad information system". The response options were 0 (no) or 1 (yes). We took the mean of all five items and used the standardized scores for interaction analyses.

\section{High-involvement HRM systems}

Based on the previous measures of high-involvement HRM practices (Guthrie 2001; Lawler 1992), we assessed high-involvement HRM systems using 6 items: "an empowering climate to encourage employee innovation", "self-management teams", "cross-functional teams", "formal employee suggestion mechanisms", "employees' right to make suggestions using information systems" and "job rotation opportunities". We followed the dichotomous approach used in previous studies (Beugelsdijk 2008; Gooderham et al. 1999) and provided response options of 0 (no) or 1 (yes). The means of all six items were used as the scores of the scale, and the standardized scores were used for interaction analyses.

\section{Social network}

We measured social networks as the number of connections with external organizations (Nambisan and Sawhney 2011). As prior research suggested that market network heterogeneity has a differential effect on innovation diffusion (Bohlmann et al. 2010), we included several categories of networks: connections with suppliers, customers, governmental agencies and research institutions in universities. Respondents were asked to indicate the number of connections they had, and the response options were 1 (none), 2 (1-5 connections), 3 (5-10 connections), 4 (10-20 connections) and 5 (20 or more connections). The means of all items were taken, and the standardized scores were used for interaction analyses.

\section{Control variables}

Previous innovation research has suggested that many factors may influence the innovation performance of organizations. A previous meta-analysis has shown that organizational size has a significant and positive relationship with innovation (Camison-zomoza et al. 2004). Thus, we controlled for organizational size, which was measured by the number of employees. Consistent with the previous research (Damanpour 1996), we also controlled for the company's industry (IT) and organizational age (lg value). In 
addition, the previous year's performance and investment in R\&D were shown to have an impact on innovation outcomes in the current year (Rothaermel and Hess 2007; Zahra and Nielsen 2002). In accordance with previous studies, we controlled for the company's total assets, revenue and R\&D investment, which were based on archival data (Crossan and Apaydin 2010; Damanpour 1991). In addition, we controlled for several factors that may have a significant impact in the Chinese context. Prior research has suggested that the company type (including state-owned enterprises (SOEs), private companies and foreign-invested enterprises (FIEs)) and whether the company is publicly listed has a significant impact on Chinese organizations' innovation outcomes (Wang and Zang 2005). We created two dummy variables for SOEs and private companies, and the comparison group is FIEs, which include both wholly foreign-invested enterprises and joint ventures (Turban et al. 2001). In addition, SOEs, private companies and FIEs have important political and economic attributes in China, which have significant managerial implications (Cuervo-Cazurra and Dau 2009; Turban et al. 2001); we ran all analyses among the three sub-samples.

\section{Reliability and validity}

Using structural equation modelling with LISREL (Joreskog and Sorbom 1993), we conducted confirmatory factor analysis (CFA) and utilized the CR and AVE values to evaluate the reliability and validity of the study measures (Bagozzi and Yi 1988). First, we performed a CFA on both the bureaucratic structure and high-involvement HR systems. The model fit indexes were $\chi^{2}(d f)=60.51(35), p<0.05 ; \chi^{2} / d f=1.73$; $\mathrm{RMR}=0.006$; GFI $=0.98$; NFI $=0.92$; $\mathrm{TLI}=0.95 ; \mathrm{CFI}=0.97$ and $\mathrm{RMSEA}=0.034$. According to the criteria suggested by Bentler (1990), the data provided support for the two-factor structure of the bureaucratic structure and high-involvement practices. In addition, for bureaucratic practices, $\mathrm{CR}=0.68, \mathrm{AVE}=0.44$; for high-involvement practices, $\mathrm{CR}=0.70, \mathrm{AVE}=0.47$. Bagozzi and $\mathrm{Yi}$ (1988) suggested that if $\mathrm{CR} \geq 0.60$ and $\mathrm{AVE} \geq 0.50$, then the constructs could be considered reliable. The AVE value of .47 is slightly lower than .50 , suggesting a slightly lower convergent validity of the two constructs than the suggested values. We calculated the smaller AVE value of both constructs, which was greater than the square value of the correlation between the two variables, suggesting good discriminant validity between the two constructs (Fornell and Larcker 1981).

Using a similar approach, we examined the fit indexes of the one-factor structure of social networks: $\chi^{2} / d f=1.07$; RMR $=0.015$; $\mathrm{GFI}=0.998 ; \mathrm{NFI}=0.988$; $\mathrm{TLI}=0.998$; $\mathrm{CFI}=0.999$ and $\mathrm{RMSEA}=0.010$. For this one-dimensional social network construct, $\mathrm{CR}=0.55$ and $\mathrm{AVE}=0.51$, which suggests that the social network construct has good reliability and convergent validity. 


\section{Results}

Table 1 displays the means, standard deviation and correlations among the variables. SOEs had more social networks $(r=0.20, p<0.01)$, patents $(r=0.25, p<0.01)$ and NPD $(r=0.23, p<0.01)$ and introduced more NPD to the market $(r=0.16$, $p<0.01)$ than others. Private organizations had lower-involvement HRM systems $(r=-0.13, p<0.01)$ and possessed fewer social networks $(r=-0.16, p<0.01)$ but generated more revenue from NPD $(r=0.18, p<0.01)$ than others. Publicly listed organizations generated less revenue from NPD than nonpublicly listed organizations $(r=-0.09, p<0.05)$. Organizations in the IT industry introduced more NPD to the market $(r=0.19, p<0.01)$ and generated higher revenue from NPD $(r=0.25$, $p<0.01)$. Firm age was not associated with any innovation outcomes, whereas firm size was positively related to three outcomes: the number of patents $(r=0.38$, $p<0.01)$, NPD $(r=0.25, p<0.01)$ and NPD introduced to the market $(r=0.22$, $p<0.01)$. We also controlled for the previous year's organizational revenue, which was positively related to the number of patents $(r=2.8, p<0.01)$, NPD $(r=0.13$, $p<0.01)$ and NPD introduced to the market $(r=0.19, p<0.01)$. The previous year's R\&D investment was positively related to all innovation outcomes: patents $(r=0.28$, $p<0.01)$, NPD $(r=0.18, p<0.01)$, NPD introduced to the market $(r=0.21, p<0.01)$ and revenue from NPD $(r=0.13, p<0.01)$.

\section{Main effects}

We used hierarchical regression to test the study hypotheses. Tables 2 and 3 summarize the regression results predicting innovation outcomes and the commercialization of innovation, respectively. For each type of outcome, we first ran the analysis using all respondents, then split the sample into SOEs, private companies, and FIEs and ran the analysis within each sub-sample. As shown in Models 9, 17 and 25 , the bureaucratic structure was negatively related to NPD $(b=-0.15, p<0.001)$, NPD introduced to the market $(b=-0.11, p<0.01)$ and revenue generated from NPD $(b=-0.09, p<0.05)$. Split-sample analyses further revealed that the negative effect of bureaucracy on the innovation outcome only existed among SOEs: patents $(b=-0.13, p<0.05)$, NPD $(b=-0.23, p<0.001)$, NPD introduced to the market $(b=-0.19, p<0.01)$ and revenues from NPD $(b=-0.17, p<0.01)$.

The results in Models 1 and 9 show that high-involvement HRM systems were positively related to the number of patents $(b=0.12, p<0.01)$ and NPD $(b=0.09$, $p<0.05)$. Split-sample analyses showed that the positive effect of high-involvement HRM systems applied to both SOEs $(b=0.15, p<0.05$ for patents and $b=0.09$, $p<0.13$ for NPD) and private companies ( $b=0.26, p<0.01$ for patents and $b=0.22$, $p<0.01$ for NPD). High-involvement HRM systems were not significantly related to the commercialization of innovation in the overall sample, but split-sample analyses suggested that high-involvement HRM systems were positively related to NPD introduced to the market among private companies $(b=0.19, p<0.05)$ and negatively related to NPD introduced to the market among FIEs $(b=-0.16, p<0.05)$. 


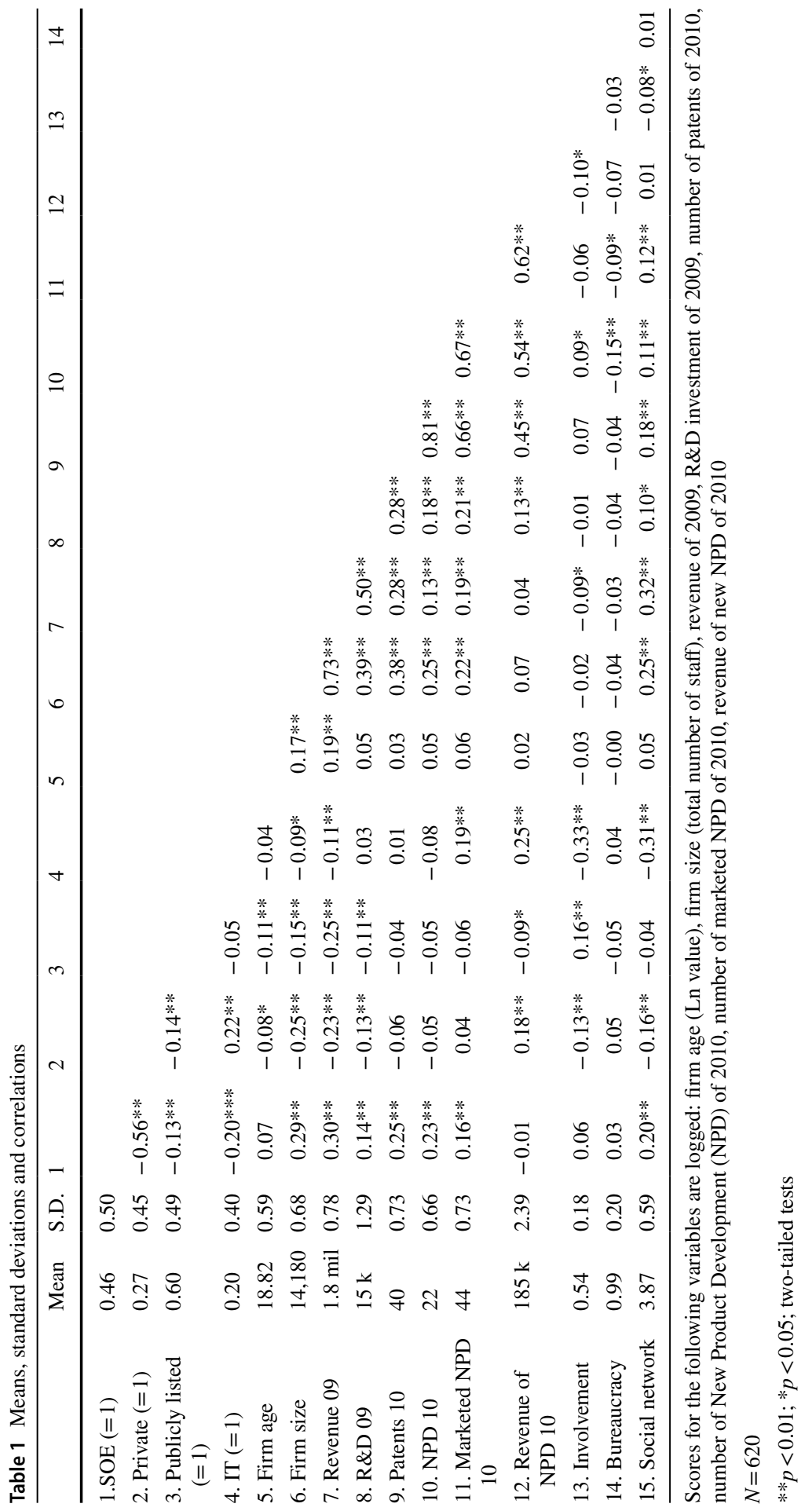




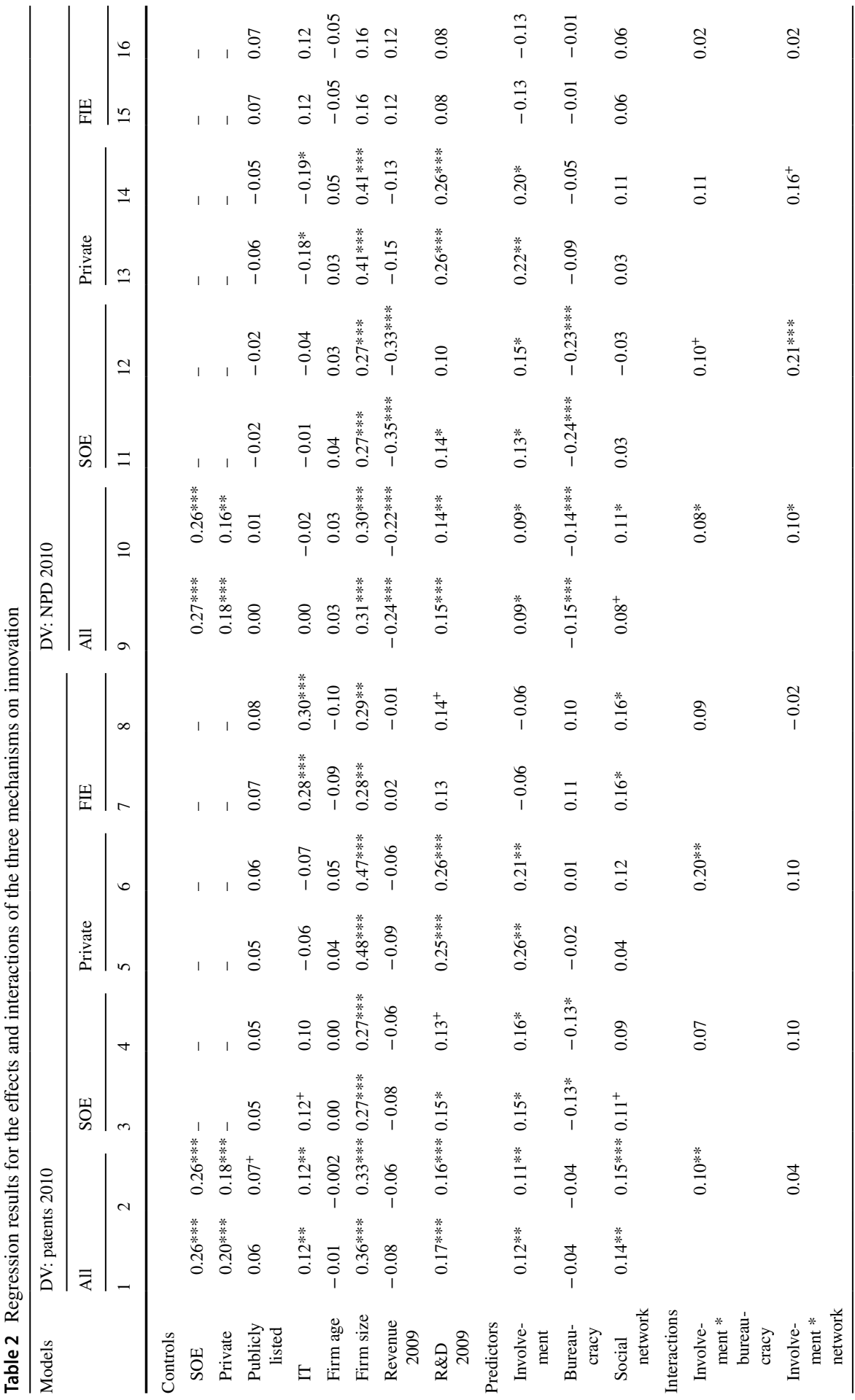




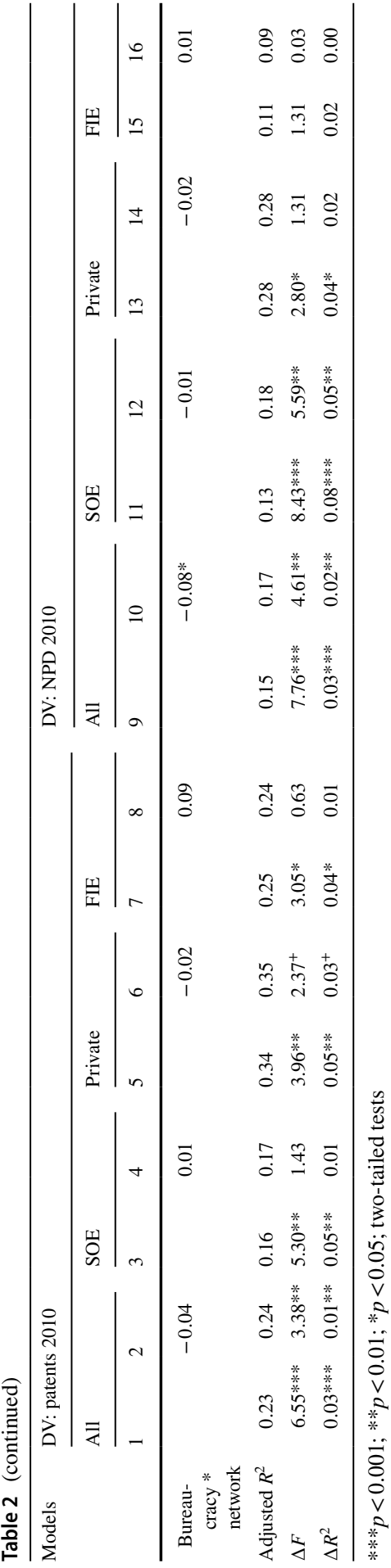

站。 


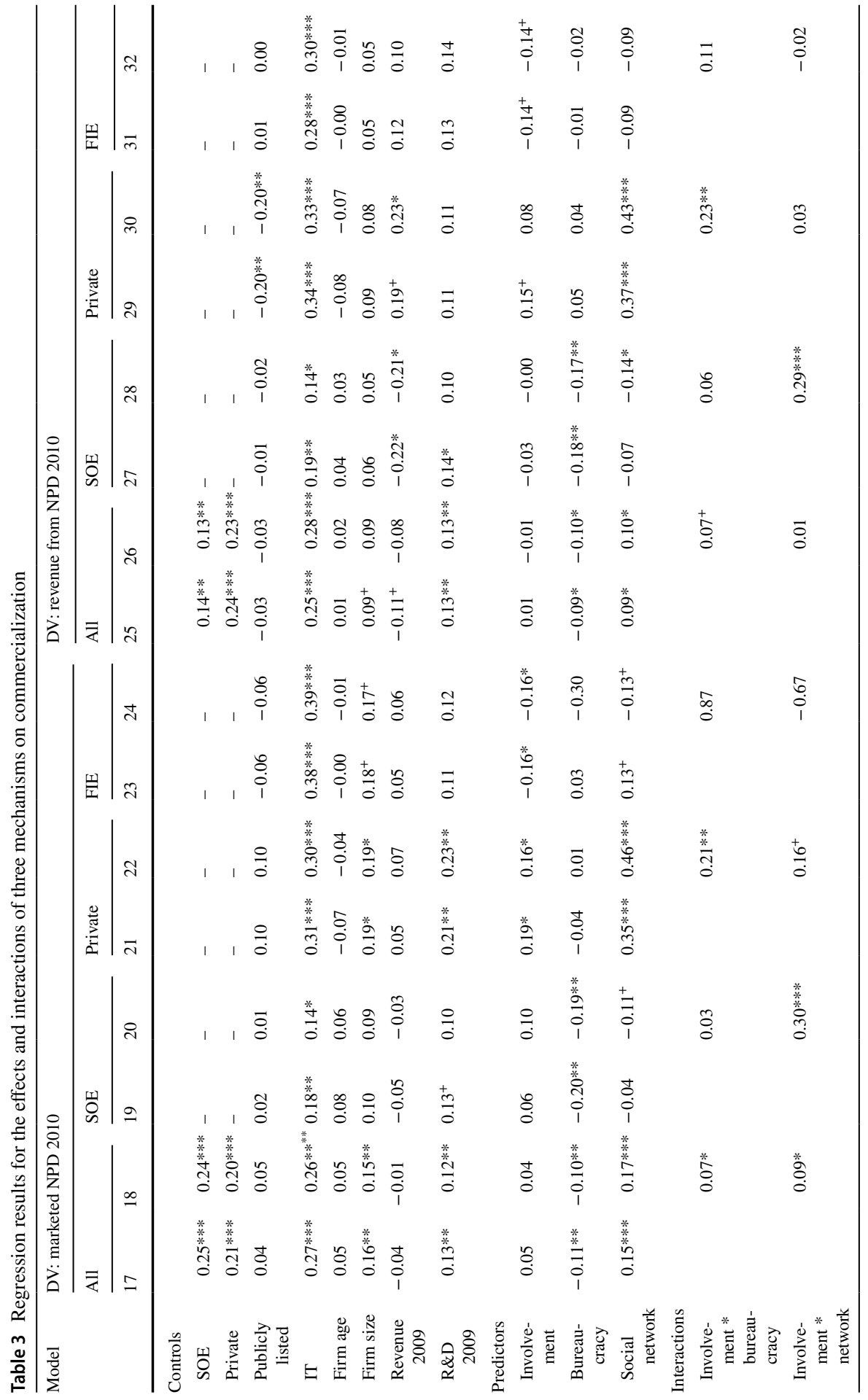




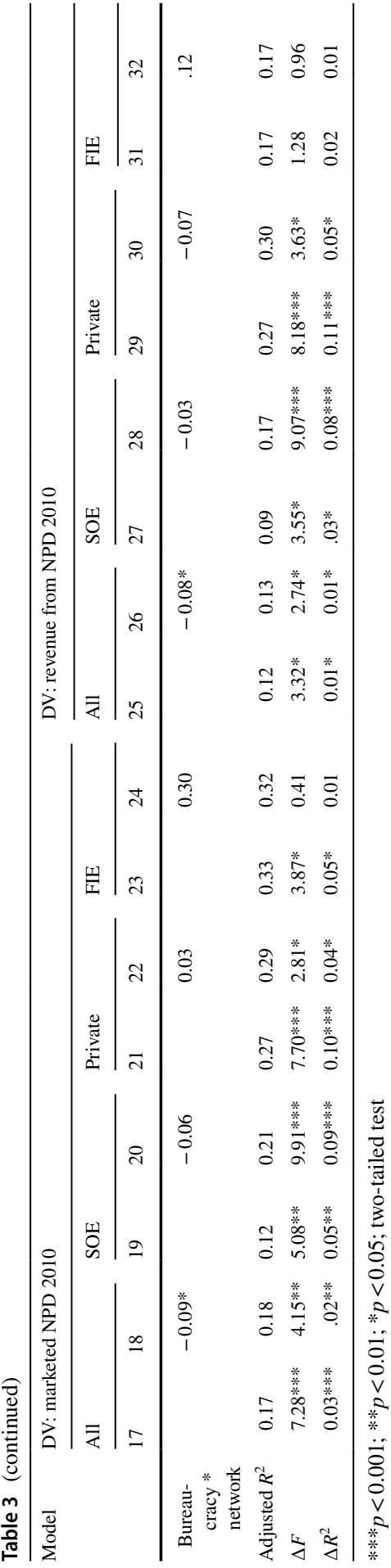

앙 
The results in Models 1, 17 and 25 show that the outreaching network was positively associated with the number of patents $(b=0.14, p<0.01)$, NPD introduced to the market $(b=0.15, p<0.001)$ and revenue generated from NPD $(b=0.09$, $p<0.05)$. Split-sample analyses further showed that social networks were positively related to patents among FIEs $(b=0.16, p<0.05)$. In addition, social networks were only significantly related to NPD introduced to the market $(b=0.35, p<0.001)$ and revenues from NPD $(b=0.37, p<0.001)$ among private companies.

\section{Interactional effects}

Hypothesis 1 predicts that the bureaucratic structure and high-involvement HRM positively interact to influence both forms of innovation. The results in Models 2 and 10 show full support for Hypothesis 1a: the interaction term was positively associated with the number of patents $(b=0.10, p<0.01)$ and NPD $(b=0.08, p<0.05)$. Following the procedures for plotting interactions (Aiken and West 1991), we presented the interactions in Fig. 1, which show that when the structure was bureaucratic, high-involvement HRM systems were more positively related to the invention stage of innovation (including the number and NDP) and the number of NPD introduced to the market. In particular, split-sample analyses revealed that the interaction between bureaucracy and high-involvement HRM system was significantly related to the number of patents only among private companies $(b=0.20, p<0.01$; Model $6)$. Although we did not find support for the interaction effect on the commercialization stage using the entire sample (Hypothesis $1 \mathrm{~b}$ ), the split-sample results showed that the effect was significant on NPD introduced to the market $(b=0.21, p<0.01$; Model 22) and revenue from NPD $(b=0.23, p<0.01$; Model 30$)$ only among private companies.

We also predicted a positive interaction between high-involvement HRM systems and outreaching networks (Hypothesis 2). The results show that the interaction term was significant in predicting NPD $(b=0.10, p<0.05$; Model 10) and NPD introduced to the market $(b=0.09, p<0.05$; Model 18). The interaction plots in Fig. 2 show that when there was a high-involvement HRM system, the outreaching network was more positively related to the number of NPD and the number of NPD introduced to the market than when there was a low-involvement HRM system. Thus, Hypotheses $2 \mathrm{a}$ and $2 \mathrm{~b}$ were also supported. Furthermore, split-sample analyses suggested that this interaction between high-involvement HRM systems and
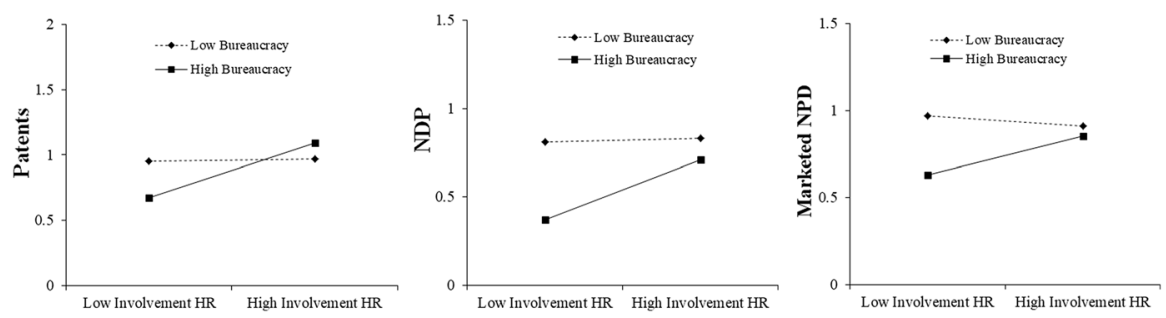

Fig. 1 Interaction of bureaucracy and involvement predicting innovation outcomes 

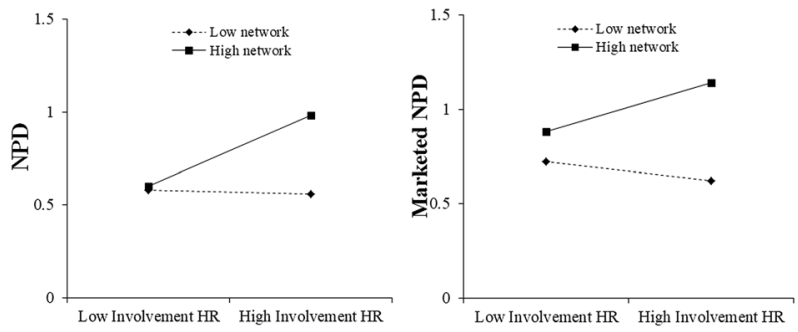

Fig. 2 Interaction of involvement and social network predicting innovation outcomes
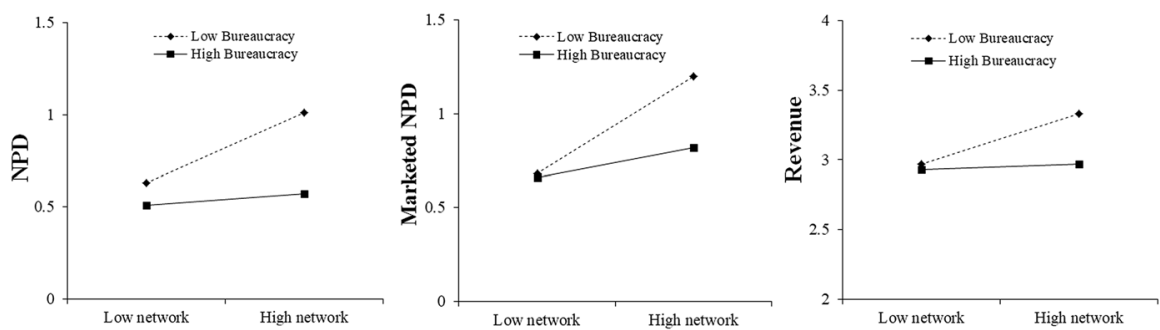

Fig. 3 Interaction of bureaucracy and social network predicting innovation outcomes

social networks was only significant among SOEs on the number of NPD $(b=0.21$, $p<0.001$; Model 12), NPD introduced to the market $(b=0.30, p<0.001$; Model 20) and revenue from NPD $(b=0.29, p<0.001$; Model 28).

Hypotheses 3 and 4 propose two possibilities that the bureaucratic structure will interact with outreaching networks to predict both stages of innovation. As shown in Models 10, 18 and 26, there were negative interactions between the bureaucratic structure and network in predicting the number of NPD $(b=-0.08, p<0.05)$, the number of NPD introduced to market $(b=-0.09, p<0.01)$ and revenue generated from NPD $(b=-0.08, b<0.05)$. We plotted the interaction in Fig. 3, which shows that when there was an organic structure, the outreaching social network was more positively related to the number of NPD, NPD introduced to the market and revenue generated from NPD than when bureaucracy was high. This finding is in accordance with the predication of Hypothesis 4 but contrary to the prediction of Hypothesis 3. However, this negative interaction effect was not significant among any of the sub-samples.

\section{Discussion}

Innovation has sparked immense interest from distinct yet complementary management areas (Ahuja et al. 2008; Damanpour and Aravind 2011). Although top-down, bottom-up and outside-in knowledge flows are all important and operate together to influence innovation, the previous research has often considered each mechanism 
separately, providing us with only a fragmented picture of how innovation is created in firms (Mom et al. 2007). This study was among the first to empirically examine the effects of bureaucracy, high-involvement HRM systems and social networks on both the invention and commercialization of innovation. In addition, we compared and contrasted the effects of the three antecedents among SOEs, private companies and FIEs. Our results from the sample of organizations in China illustrate a number of interesting, novel and important findings for both theory and practice.

\section{Theoretical implications}

Our research contributes to the existing literature in three ways: first, by adopting complementary perspectives of three mechanisms of innovation, i.e. top-down, bottom-up and outside-in, we expand the understanding of the multi-dimensional antecedents of firm innovation. Although innovation can be derived from individual, organizational and network perspectives, the majority of existing studies tend to focus on only one perspective (Mom et al. 2007; Rothaermel and Hess 2007), which inhibits the comprehensive understanding of the influencing factors of innovation. In fact, some researchers have called for proposing more comprehensive research models to integrate the predictive factors of firm innovation (Anderson et al. 2014). In this study, we respond to this call by constructing a three-dimensional predictive model of firm innovation and compare its relative impact on two stages of firm innovation. On the whole, we find that the bureaucratic structure has a negative effect on both innovation invention and commercialization and that the social network is positively related to both innovation invention and commercialization, while the highinvolvement HRM system is only positively related to innovation invention but not commercialization. Our results provide more detailed evidence supporting the positive effect of employee involvement and social networks and the detrimental influence of the bureaucratic structure on firm innovation.

Second, through split-sample analysis in terms of firm ownership, we contribute to the literature on the boundary conditions (i.e. firm ownership styles) of the effects of the bureaucratic structure, high-involvement HRM system and social network. Although the previous studies have tended to focus on the dark side of the bureaucratic structure (e.g. Li et al. 2018a), our results show that the negative relationship is significant only for SOEs. In other words, the bureaucratic structure is not always destructive for innovation in all kinds of firms, which may deepen our understanding of the complicated influence of the bureaucratic structure. For high-involvement HRM systems, although researchers speak highly of its positive effect on innovation (Bhattacharya et al. 2005; De Dreu and West 2001; Martínez-Sánchez et al. 2011; Shin et al. 2016; Zhou et al. 2019), our results show that it is only positively related to the first stage of innovation (i.e. innovation invention) for SOEs, and more notably, high-involvement HRM systems are negatively related to the second stage of innovation (i.e. innovation commercialization) for FIEs. Thus, we should also pay attention to the dark side of the high-involvement HRM system. Regarding the social network, although it is useful for both innovation invention and commercialization on the whole, for 
different types of enterprises, its influence may also be different. For example, we find that the social network is positively related to the first and second stage of innovation for SOEs and private enterprises, respectively, and to both innovation stages for FIEs, which reminds us that the influence of the social network may hinge on firm type and different stages of innovation.

Third, by synthesizing three interdisciplinary perspectives and simultaneously considering innovative dynamics as top authority-driven, employee-driven and network-driven, we proposed an integrated and synergistic framework for firm innovation. The examination of one source of innovation independently may present a partial picture of innovation, and in fact, Anderson et al. (2014) have suggested that one of the most valuable venues for future research is to propose "models and theoretical propositions to explain cross-level and multilevel innovation" (p. 1318). In this study, we find that although a bureaucratic structure is negatively related to both stages of innovation and that a high-involvement HRM system is only positively related to the innovation invention stage, when interacting with each other, they can exert a positive effect on both stages of innovation. That is, the bureaucratic structure (managing innovation from the "top-down") and high-involvement HRM system (motivating innovation from the "bottomup") can complement each other to influence firm innovation. In addition, we also find a positive interaction effect between "bottom-up" high-involvement HRM systems and "outside-in" social networks on both stages of firm innovation, which echoes the previous research finding that human capital can positively leverage the effectiveness of social capital (Subramaniam and Youndt 2005; Zahra and Nielsen 2002).

We had proposed two competing possibilities that organizations need or do not need a strong bureaucratic structure to effectively integrate and coordinate the innovative resources residing in the network. We found that strong bureaucracy in fact attenuated the effectiveness of external network connections in promoting firm innovation invention and commercialization. In other words, if bureaucratic organizations are too rigid to make compromises in the resource exchange, they may lose many important opportunities to share innovation resources.

In sum, this study not only examined the effects of three typical mechanisms (i.e. authority-driven, employee-driven and network-driven mechanisms) on two stages of innovation but also revealed the complex, pluralistic interactions between these mechanisms. This extended the dual equilibrium of organization dynamics in innovation processes to a triadic perspective. Previous researchers have suggested that dynamic innovation processes require a compatible balance of contradictory tensions simultaneously or over time, such as the balance of efficiency and flexibility (Thompson 1967), organic and mechanistic structures (Burns and Stalker 1961), routines and switching routines (Weick 1979), exploration and exploitation (March 1991), and centralization and decentralization (Nickerson and Zenger 2002). Our study further delineates a triadic dynamic equilibrium among the three mechanisms of top-down bureaucracy, bottom-up involvement and outreaching social network. Using a metaphor, the results suggest that an effective innovator should be a good juggler who plays well with three balls rather than two. 


\section{Limitations and future directions}

We have taken a few steps to minimize common method bias, including using both surveys and the objective data of innovation outcomes, as well as having a year's time lag between the measurement of the organizational mechanism and innovation outcomes. Nonetheless, there are certain cautions that should be taken in interpreting and generalizing the results of the current study, which, in turn, also open pathways to future research.

The first is the potential contextual influence on the study results. Our study data were collected from China; although this supplements the research on innovation that was predominantly conducted in the Western context, contextual factors may have influenced the generalizability of our empirical results in a complex manner. For example, there may be greater proportions of SOEs (45.6\%) in China than in Western countries. However, researchers suggest that SOEs are also quite prevalent in the West, in sectors such as telecommunications, energy, mass transit, healthcare and postal services (Wang and Qian 2011). In addition, the "cognitive conservatism" developed through a history of Confucius-heritage education in China was thought to develop individual obedience to authority, thereby inhibiting individual initiative taking and creativity (Ho and Ho 2008). In such a context, a bureaucratic structure and high-involvement HRM systems may operate in a different manner than in the Western context. In particular, we found moderate variance within the samples in terms of bureaucracy (mean $=0.99, \mathrm{SD}=0.20$ ) and no significant difference in bureaucracy between the sub-samples. This may have limited the magnitude of the relationships between bureaucracy and other variables that were observed in this study. Nonetheless, globalization drives practices across different countries to gradually converge; thus, contextual factors should not have altered the substantiality of our findings. Finally, our sample appeared to be more clustered in the energy and high-tech sectors and to have more FIEs compared to the general organization population suggested by the National Statistics Bureau. We thus call for future studies to further test the model in other cross-national samples and in other sectors such as construction, transport, wholesale and retail, services, education and public management.

Second, due to the scope of the current study, we considered the three predictors as holistic constructs, without further breaking them down into sub-dimensions. Further research may extend the present model by introducing the sub-dimensions of the three mechanisms, such as the centralization and formalization of organizational bureaucracy and vertical and horizontal network connections, to examine their specific effects on innovation in depth. We have focused on the content of network connections, and future research may also specify different characteristics of networks, such as an open/closed network, dense/sparse network, strong/weak ties, direct/indirect ties and network positions (Ahuja 2000; Ahuja et al. 2008), to further explicate their effects. In addition, our research findings also open up new directions for introducing other dominant mechanisms into the model. For example, recent research has suggested that organizational goal orientation has a significant influence on bureaucratic structures and employee innovation (Hirst et al. 2011). We deduce that it may help explain the duality effect of organizational bureaucracy; future research may 
further examine the interaction between innovation goal orientation and bureaucracy innovation.

Finally, this study employed very rigorous data collection procedures, using a multi-source and 1-year time lag design to reduce common method bias. However, it should be noted that we do not make causal inferences based on our findings, which will require future research to further replicate this model using true a longitudinal design and preferably with a longer time lag for the innovation measures. In addition, we measured all study variables at the organizational level. We echo previous scholars in calling for further research to examine the cross-level influence process on innovation outcomes (Gupta et al. 2007; Rothaermel and Hess 2007; Woodman et al. 1993).

\section{Practical implications}

We examine three mechanisms that have been considered important components of organizational managerial innovation (Damanpour and Aravind 2011), all of which offer immediate and actionable implications. Our results suggest that it is paramount that managers are not only able to weigh the strengths and weaknesses of various innovation mechanisms in the context of different organizations but also able to understand how different mechanisms will interact when used in tandem. First, conventional wisdom has led many managers to believe that bureaucracy will stifle innovative ideas. Such beliefs may ignore the bigger picture in that a certain degree of bureaucracy can be helpful for directing and guiding employee behaviours when they are managed in a high-involvement HRM system. This is particularly true for private companies that are younger and smaller in size than other types of organizations in China. The metaphor of the river and the bank has been used to illustrate the importance of a bureaucratic structure (river bank) in guiding the free actions (river flow) of individuals (Blanchard et al. 1996). For optimal flow, the river bank should not be too narrow (rules and guidelines are too specific), which would limit the speed of the flow; nor should it be too shallow (very few rules and guidelines), which would not be able to contain the rapid flow, thereby leading to chaotic floods. A useful suggestion that stems from this research, therefore, is for private company managers who are contemplating actions that can balance the effectiveness and efficiency of innovative efforts to supplement a centralized and formalized organizational system with high involvement of employees to stimulate their initiative taking and innovative actions.

In addition, the prior research has generally considered a high-involvement HRM system to be beneficial for all stages of innovation (Lawler 1992). Our results provide more specific evidence that high-involvement HRM systems are most effective for managing the invention stage of innovation or knowledge workers who are responsible for new technology and product development (Lepak and Snell 1999). However, if managers are focusing on strengthening the administrative systems to facilitate the integration of the invention and commercialization of innovation, blind-mindedly empowering employees may lead to a lack of a unified goal and diversification of resources, which is evident among FIEs in China. 
Our research also demonstrates that in an era of network-centric innovation (Lichtenthaler 2011; Nambisan and Sawhney 2011), organizations that continue to rely on internal impetus for innovation would lose many valuable resources and opportunities to those that connect with various external sources for innovation. In addition, the effect of connecting with external social networks is amplified when organizations implement high-involvement HRM systems to fully absorb and digest the resources obtained from external sources. This synergy between social networks and high-involvement HRM systems is especially applied to SOEs in China, which have inherited rich network connections but may lack the internal capabilities to exploit network resources for innovation. However, a bureaucratic structure would in contrast impede such assimilation processes of external network resources. This has implications for managers implementing network-centric innovation in that they should be wary of integrating complementary internal and external capabilities (Lichtenthaler and Lichtenthaler 2010) to effectively integrate internal high involvement with external network connections while, at the same time, controlling the tendency to overly exert power brought about by a bureaucratic structure but maintaining an equal platform for effective collaboration with external partners (Nambisan and Sawhney 2011).

\section{Conclusion}

Organizational innovation is a highly uncertain and unpredictable process, analogous to walking on a thin rope. A normal innovator is similar to a funambulist, who attempts to balance both sides. Our research provides three poles for optimal balance: top-down from the organizational level (bureaucratic structure), bottom-up from the individual level (high-involvement HRM system) and outside-in from the network level (outreaching network); a superior innovator should be able to simultaneously integrate and adjust all three mechanisms. Using a sample of organizations in China, this study not only examined the effects of three typical mechanisms on innovation but also revealed the complex, pluralistic interactions among these mechanisms. Our results provide important implications for the successful management of organizational innovation by compatibly coordinating the triad.

Acknowledgements On behalf of all authors, the corresponding author states that there is no conflict of interest.

Open Access This article is distributed under the terms of the Creative Commons Attribution 4.0 International License (http://creativecommons.org/licenses/by/4.0/), which permits unrestricted use, distribution, and reproduction in any medium, provided you give appropriate credit to the original author(s) and the source, provide a link to the Creative Commons license, and indicate if changes were made.

\section{References}

Adler, P. S., \& Borys, B. (1996). Two types of bureaucracy: Enabling and coercive. Administrative Science Quarterly, 41(1), 61-89. 
Ahuja, G. (2000). Collaboration networks, structural holes, and innovation: A longitudinal study. Administrative Science Quarterly, 45(3), 425-455.

Ahuja, G., Lampert, C. M., \& Tandon, V. (2008). Chapter 1: Moving beyond schumpeter: Management research on the determinants of technological innovation. Academy of Management Annals, 2(1), $1-98$.

Aiken, L. S., \& West, S. G. (1991). Multiple regression: Testing and interpreting interactions. Newbury Park, CA: Sage.

Anderson, N., Potočnik, K., \& Zhou, J. (2014). Innovation and creativity in organizations: A state-of-thescience review, prospective commentary, and guiding framework. Journal of Management, 40(5), 1297-1333.

Baer, M. (2012). Putting creativity to work: The implementation of creative ideas in organizations. Academy of Management Journal, 55(5), 1102-1119.

Bagozzi, R. P., \& Yi, Y. (1988). On the evaluation of structural equation models. Journal of the Academy of Marketing Science, 16(1), 74-94.

Becker, B. E., \& Huselid, M. A. (1998). High performance work systems and firm performance: A synthesis of research and managerial implications. Research in Personnel and Human Resources Management, 16, 53-101.

Bentler, P. M. (1990). Comparative fit indexes in structural models. Psychological Bulletin, 107(2), 238-246.

Beugelsdijk, S. (2008). Strategic human resource practices and product innovation. Organization Studies, 29(6), 821-847.

Bhattacharya, M., Gibson, D. E., \& Doty, D. H. (2005). The effects of flexibility in employee skills, employee behaviors, and human resource practices on firm performance. Journal of Management, 31(4), 622-640.

Blanchard, K. H., Carlos, J. P., \& Randolph, W. A. (1996). Empowerment takes more than a minute. San Francisco: Berrett-Koehler.

Bohlmann, J. D., Calantone, R. J., \& Meng, Z. (2010). The effects of market network heterogeneity on innovation diffusion: An agent-based modeling approach. Journal of Product Innovation Management, 27(5), 741-760.

Bolin, M., \& Härenstam, A. (2008). An empirical study of bureaucratic and post-bureaucratic characteristics in 90 workplaces. Economic \& Industrial Democracy, 29(4), 541-564.

Bornay-Barrachina, M., López-Cabrales, A., \& Valle-Cabrera, R. (2016). How do employment relationships enhance firm innovation? The role of human and social capital. The International Journal of Human Resource Management, 28(9), 1363-1391.

Boxall, P., \& Macky, K. (2009). Research and theory on high-performance work systems: Progressing the high-involvement stream. Human Resource Management Journal, 19(1), 3-23.

Brem, A., Maier, M., \& Wimschneider, C. (2016). Competitive advantage through innovation: the case of Nespresso. European Journal of Innovation Management, 19(1), 133-148.

Bunderson, J. S., \& Boumgarden, P. (2010). Structure and learning in self-managed teams: Why "bureaucratic" teams can be better learners. Organization Science, 21(3), 609-624.

Burns, T., \& Stalker, G. M. (1961). The management of innovation. London: Tavistock Publications.

Burt, R. S. (2004). Structural holes and good ideas. American Journal of Sociology, 110(2), 349-399.

Camison-zomoza, C., Lapiedra-alcamí, R., Segarra-cipres, M., \& Boronat-navarro, M. (2004). a metaanalysis of innovation and organizational size. Organization Studies, 25(3), 331-361.

Christensen, C. M., \& Bower, J. L. (1996). Customer power, strategic investment, and the failure of leading firms. Strategic Management Journal, 17(3), 197-218.

Cooke, P., \& Morgan, K. (1998). The associational economy: Firms. Regions and Innovation: Oxford University Press.

Crossan, M. M., \& Apaydin, M. (2010). A multi-dimensional framework of organizational innovation: A systematic review of the literature. Journal of Management Studies, 47(6), 1154-1191.

Cuervo-Cazurra, A., \& Dau, L. A. (2009). Promarket reforms and firm profitability in developing countries. Academy of Management Journal, 52(6), 1348-1368.

Damanpour, F. (1991). Organizational innovation: A meta-analysis of effects of determinants and moderators. Academy of Management Journal, 34(3), 555-590.

Damanpour, F. (1996). Bureaucracy and innovation revisited: Effects of contingency factors, industrial sectors, and innovation characteristics. Journal of High Technology Management Research, 7(2), $150-173$. 
Damanpour, F., \& Aravind, D. (2011). Managerial innovation: Conceptions, processes, and antecedents. Management \& Organization Review, 8(2), 423-454.

De Dreu, C. K. W., \& West, M. A. (2001). Minority dissent and team innovation: The importance of participation in decision making. Journal of Applied Psychology, 86(6), 1191-1201.

Dhanaraj, C., \& Parkhe, A. (2006). Orchestrating innovation networks. Academy of Management Review, 31(3), 659-669.

Eisenhardt, K. M., \& Martin, J. A. (2000). Dynamic capabilities: What are they? Strategic Management Journal, 21(10-11), 1105-1121.

Ettlie, J. E., Bridges, W. P., \& O'Keefe, R. D. (1984). Organization strategy and structural differences for radical versus incremental innovation. Management Science, 30(6), 682-695.

Eva, N., Prajogo, D., \& Cooper, B. (2017). The relationship between personal values, organizational formalization and employee work outcomes of compliance and innovation. International Journal of Manpower, 38(2), 274-287.

Fornell, C., \& Larcker, D. F. (1981). Structural equation models with unobservable variables and measurement error: Algebra and statistics. Journal of Marketing Research (JMR), 18(3), 382-388.

Gilson, L. L., Mathieu, J. E., Shalley, C. E., \& Ruddy, T. M. (2005). Creativity and standardization: Complementary or conflicting drivers of team effectiveness? Academy of Management Journal, 48(3), 521-531.

Gooderham, P. N., Nordhaug, O., \& Ringdal, K. (1999). Institutional and rational determinants of organisational practices: Human Resource management in European firms. Administrative Sciences Quarterly, 44(3), 507-531.

Guan, J., Zhang, J., \& Yan, Y. (2015). The impact of multilevel networks on innovation. Research Policy, 44(3), 545-559.

Gulati, R. (1999). Network location and learning: The influence of network resources and firm capabilities on alliance formation. Strategic Management Journal, 20(5), 397-420.

Gupta, A. K., Tesluk, P. E., \& Taylor, M. S. (2007). Innovation at and across multiple levels of analysis. Organization Science, 18(6), 885-897.

Guthrie, J. P. (2001). High-involvement work practices, turnovers, and productivity: Evidence from New Zealand. Academy of Management Journal, 44(1), 180-190.

Hage, J., \& Aiken, M. (1967). Relationship of centralization to other structural properties. Administrative Science Quarterly, 12(1), 72-92.

Hansen, S.-O., \& Wakonen, J. (1997). Innovation, a winning solution? International Journal of Technology Management, 13(4), 345-358.

Harhoff, D. (1996). Strategic spillovers and incentives for research and development. Management Science, 42(6), 907-925.

He, X., Yi, Y., \& Wei, Z. (2019). New product development capabilities in China: The moderating role of TMT cooperative behavior. Asian Business \& Management, 18(2), 73-97.

Hempel, P. S., Zhang, Z.-X., \& Han, Y. (2012). Team empowerment and the organizational context: Decentralization and the contrasting effects of formalization. Journal of Management, 38(2), $475-501$.

Herrera, M. E. B. (2015). Creating competitive advantage by institutionalizing corporate social innovation. Journal of Business Research, 68(7), 1468-1474.

Hirst, G., Van Knippenberg, D., Chen, C.-H., \& Sacramento, C. A. (2011). How does bureaucracy impact individual creativity? A cross-level investigation of team contextual influences on goal orientationcreativity relationships. Academy of Management Journal, 54(3), 624-641.

Hlavacek, J. D., \& Thompson, V. A. (1973). Bureaucracy and new product innovation. Academy of Management Journal, 16(3), 361-372.

Ho, D. Y. F., \& Ho, R. T. H. (2008). Knowledge is a dangerous thing: Authority relations, ideological conservatism, and creativity in confucian-heritage cultures. Journal for the Theory of Social Behaviour, 38(1), 67-86.

Howard, M., Steensma, H. K., Lyles, M., \& Dhanaraj, C. (2016). Learning to collaborate through collaboration: How allying with expert firms influences collaborative innovation within novice firms. Strategic Management Journal, 37(10), 2092-2103.

Huang, K. E., Wu, J. H., Lu, S. Y., \& Lin, Y. C. (2016). Innovation and technology creation effects on organizational performance. Journal of Business Research, 69(6), 2187-2192.

Jackson, S. E., \& Schuler, R. S. (1995). Understanding Human Resource Management in the context of organizations and their environments. In M. R. Rosenweig \& L. W. Porter (Eds.), Annual review of psychology (pp. 237-264). Palo Alto: Annual Reviews Inc. 
James, S. D., Leiblein, M. J., \& Lu, S. (2013). How firms capture value from their innovations. Journal of Management, 39(5), 1123-1155.

Jansen, J. J. P., Van Den Bosch, F. A. J., \& Volberda, H. W. (2005). Managing potential and realized absorptive capacity: How do organizational antecedents matter? Academy of Management Journal, 48(6), 999-1015.

Jansen, J. J. P., Van Den Bosch, F. A. J., \& Volberda, H. W. (2006). Exploratory innovation, exploitative innovation, and performance: Effects of organizational antecedents and environmental moderators. Management Science, 52(11), 1661-1674.

Jia, N., Huang, K. G., \& Man Zhang, C. (2019). Public governance, corporate governance, and firm innovation: An examination of state-owned enterprises. Academy of Management Journal, 62(1), 220-247.

Jing, L., Xia, J., Zajac, E. J., Jing, L., Xia, J., Zajac, E. J., et al. (2017). On the duality of political and economic stakeholder influence on firm innovation performance: Theory and evidence from Chinese firms. Strategic Management Journal, 39(1), 193-216.

Joreskog, K. G., \& Sorbom, D. (1993). LISREL 8: Structural equation modeling with the SIMPL1S command language. Lisrel Structural Equation Modeling with the Simplis Command Language.

Kang, S.-C., Morris, S. S., \& Snell, S. A. (2007). Relational archetypes, organizational learning, and value creation: Extending the human resource architecture. Academy of Management Review, 32(1), 236-256.

Kang, S.-C., \& Snell, S. A. (2009). Intellectual capital architectures and ambidextrous learning: A framework for human resource management. Journal of Management Studies, 46(1), 65-92.

Kesting, P., \& Ulhøi, J. P. (2010). Employee-driven innovation: Extending the license to Foster innovation. Management Decision, 48(1), 65-84.

Keum, D. D., \& See, K. E. (2017). The influence of hierarchy on idea generation and selection in the innovation process. Organization Science, 28(4), 653-669.

Kianto, A., Sáenz, J., \& Aramburu, N. (2017). Knowledge-based human resource management practices, intellectual capital and innovation. Journal of Business Research, 81, 11-20.

Kijkuit, B., \& van den Ende, J. (2007). The organizational life of an idea: Integrating social network, creativity and decision-making perspectives. Journal of Management Studies, 44(6), 863-882.

Knight, A. P., Menges, J. I., \& Bruch, H. (2018). Organizational affective tone: A meso perspective on the origins and effects of consistent affect in organizations. Academy of Management Journal, 61(1), 191-219.

Lawler, E. E. (1992). The ultimate advantage: Creating the high-involvement organization. San Francisco: Jossey-Bass.

Lepak, D. P., \& Snell, S. A. (1999). The human resource architecture: Toward a theory of human capital allocation and development. Academy of Management Review, 24(1), 31-48.

Li, C.-R., Li, C.-X., \& Lin, C.-J. (2018a). How and when team regulatory focus influences team innovation and member creativity. Personnel Review, 47(1), 95-117.

Li, Y., Wang, M., Jaarsveld, D. D., Lee, G. K., \& Ma, D. G. (2018b). From employee-experienced high-involvement work system to innovation-An emergence-based human resource management framework. Academy of Management Journal, 61(5), 2000-2019.

Lichtenthaler, U. (2011). Open innovation: Past research, current debates, and future directions. Academy of Management Perspectives, 25(1), 75-93.

Lichtenthaler, U., Ernst, H., \& Hoegl, M. (2010). Not-sold-here: How attitudes influence external knowledge exploitation. Organization Science, 21(5), 1054-1071.

Lichtenthaler, U., \& Lichtenthaler, E. (2010). A capability-based framework for open innovation: Complementing absorptive capacity. Journal of Management Studies, 46(8), 1315-1338.

Lin, X., \& Germain, R. (2003). Organizational structure, context, customer orientation, and performance: Lessons from Chinese state-owned enterprises. Strategic Management Journal, 24(11), 1131-1151.

Lundvall, B.-A. (1992). National systems of innovation. Towards a theory of innovation and interactive learning. London: Pinter Publishers.

Luong, H., Moshirian, F., Nguyen, L., Tian, X., \& Zhang, B. (2017). How do foreign institutional investors enhance firm innovation? Journal of Financial and Quantitative Analysis, 52(4), 1449-1490.

Madigan, R. M., \& Hoover, D. J. (1986). Effects of alternative job evaluation methods on decisions involving pay equity. Academy of Management Journal, 29(1), 84-100. 
Magee, J. C., \& Galinsky, A. D. (2008). Chapter 8: Social hierarchy: The self-reinforcing nature of power and status. Academy of Management Annals, 2, 351-398.

March, J. G. (1991). Exploration and exploitation in organizational learning. Organization Science, 2(1), 71-87.

March, J. G., \& Simon, H. A. (1958). Organizations. New York: Wiley.

Martínez-Sánchez, A., Vela-Jiménez, M.-J., Pérez-Pérez, M., \& de-Luis-Carnicer, P. (2011). The dynamics of labour flexibility: Relationships between employment type and innovativeness. Journal of Management Studies, 48(4), 715-736.

Maurer, I., Bartsch, V., \& Ebers, M. (2011). The value of intra-organizational social capital: How it fosters knowledge transfer, innovation performance, and growth. Organization Studies, 32(2), $157-185$.

Mintzberg, H. (1979). The structuring of organizations. Englewood Cliffs: Prentice Hall.

Mom, T. J. M., Van Den Bosch, F. A. J., \& Volberda, H. W. (2007). Investigating managers' exploration and exploitation activities: The influence of top-down, bottom-up, and horizontal knowledge inflows. Journal of Management Studies, 44(6), 910-931.

Mueller, V., Rosenbusch, N., \& Bausch, A. (2013). Success patterns of exploratory and exploitative innovation: A meta-analysis of the influence of institutional factors. Journal of Management, 39(6), 1606-1636.

Nambisan, S., \& Sawhney, M. (2011). Orchestration processes in network-centric innovation: Evidence from the field. Academy of Management Perspectives, 25(3), 40-57.

Narin, F., Noma, E., \& Perry, R. (1987). Patents as indicators of corporate technological strength. Research Policy, 16(2-4), 143-155.

Nickerson, J. A., \& Zenger, T. R. (2002). Being efficiently fickle: A dynamic theory of organizational choice. Organization Science, 13(5), 547-566.

Oxley, J. E., \& Sampson, R. C. (2004). The scope and Governance of International R\&D alliances. Strategic Management Journal, 25(8/9), 723-749.

Peng, M. W., \& Luo, Y. (2000). Managerial Ties and firm performance in a transition economy: The nature of a micro-macro link. Academy of Management Journal, 43(3), 486-501.

Phelps, C. C. (2010). A longitudinal study of the influence of alliance network structure and composition on firm exploratory innovation. Academy of Management Journal, 53(4), 890-913.

Pierce, J. L., \& Delbecq, A. L. (1977). Organization structure, individual attitudes and innovation. Academy of Management Review, 2(1), 27-37.

Podsakoff, P. M., MacKenzie, S. B., Jeong-Yeon, L., \& Podsakoff, N. P. (2003). Common method biases in behavioral research: A critical review of the literature and recommended remedies. Journal of Applied Psychology, 88(5), 879-903.

Poskela, J., \& Martinsuo, M. (2009). Management control and strategic renewal in the front end of innovation. Journal of Product Innovation Management, 26(6), 671-684.

Powell, W. W., Koput, K. W., \& Smith-Doerr, L. (1996). Interorganizational collaboration and the locus of innovation: Networks of learning in biotechnology. Administrative Science Quarterly, 41, 116-145.

Pugh, D. S., Hickson, D. J., Hinings, C. R., Macdonald, K. M., Turner, C., \& Lupton, T. (1963). A conceptual scheme for organizational analysis. Administrative Science Quarterly, 8(3), 289-315.

Rialp-Criado, A., \& Komochkova, K. (2017). Innovation strategy and export intensity of Chinese SMEs: The moderating role of the home-country business environment. Asian Business \& Management, 16(3), 158-186.

Rothaermel, F. T., \& Hess, A. M. (2007). Building dynamic capabilities: Innovation driven by individual-, firm-, and network-level effects. Organization Science, 18(6), 898-921.

Schneider, B., Smith, D. B., \& Goldstein, H. W. (2000). Attraction-selection-attrition toward a personenvironment psychology of organizations. In K. H. Craik, R. H. Price, \& W. B. Walsh (Eds.), Person-environment psychology: New directions and perspectives (pp. 61-85). Mahwah: Lawrence Erlbaum Associates Inc.

Sears, G. J., \& Baba, V. V. (2011). Toward a multistage, multilevel theory of innovation. Canadian Journal of Administrative Sciences/Revue Canadienne des Sciences de l'Administration, 28(4), 357-372.

Shalley, C. E., Zhou, J., \& Oldham, G. R. (2004). The effects of personal and contextual characteristics on creativity: Where should we go from here? Journal of Management, 30(6), 933-958.

Shin, S. J., Jeong, I., \& Bae, J. (2016). Do high-involvement hrm practices matter for worker creativity? A cross-level approach. The International Journal of Human Resource Management, 29(2), 260-285. 
Shipton, H., West, M. A., Dawson, J., Birdi, K., \& Patterson, M. (2006). HRM as a predictor of innovation. Human Resource Management Journal, 16(1), 3-27.

Smith, W. K., \& Tushman, M. L. (2005). Managing strategic contradictions: A top management model for managing innovation streams. Organization Science, 16(5), 522-536.

Song, X. M., \& Parry, M. E. (1996). What separates Japanese new product winners from losers. Journal of Product Innovation Management, 13(5), 422-439.

Soo, C., Tian, A. W., Teo, S. T. T., \& Cordery, J. (2017). Intellectual capital-enhancing HR, absorptive capacity, and innovation. Human Resource Management, 56(3), 431-454.

Subramaniam, M., \& Youndt, M. A. (2005). The influence of intellectual capital on the types of innovative capabilities. Academy of Management Journal, 48(3), 450-463.

Teece, D. J. (1992). Competition, cooperation, and innovation: Organizational arrangements for regimes of rapid technological progress. Journal of Economic Behavior \& Organization, 18(1), 1-25.

Teece, D. J., Pisan, G., \& Shuen, A. (1997). Dynamic capabilities and strategic management. Strategic Management Journal, 18(7), 509-533.

Thompson, J. D. (1967). The structure of complex organization. In D. S. Pugh (Ed.), Organization theory: Selected readings (pp. 29-43). London: Penguin books.

Turban, D. B., Lau, C.-M., Ngo, H.-Y., Chow, I. H. S., \& Si, S. X. (2001). Organizational attractiveness of firms in the People's Republic of China: A person-organization fit perspective. Journal of Applied Psychology, 86(2), 194-206.

Ulrich, D., Kerr, S., \& Ashkenas, R. (2002). The GE “Work-Out”. New York: McGraw-Hill.

Uzzi, B. (1997). Social structure and competition in interfirm networks: The paradox of embededness. Administrative Science Quarterly, 42, 35-67.

Vanhaverbeke, W., Gilsing, V., Beerkens, B., \& Duysters, G. (2009). The role of alliance network redundancy in the creation of core and non-core technologies. Journal of Management Studies, 46(2), $215-244$.

Wang, H., \& Qian, C. (2011). Corporate philanthropy and corporate financial performance: The roles of stakeholder response and political access. Academy of Management Journal, 54(6), 1159-1181.

Wang, Z., \& Zang, Z. (2005). Strategic human resources, innovation and entrepreneurship fit: A crossregional comparative model. International Journal of Manpower, 26(6), 544-559.

Weick, K. E. (1979). The social psychology of organizing (2nd ed.). Reading: Addison-Wesley.

Woodman, R. W., Sawyer, J. E., \& Griffin, R. W. (1993). Toward a Theory of Organizational Creativity. Academy of Management Review, 18(2), 293-321.

Yang, Y., \& Shafi, M. (2019). How does customer and supplier cooperation in micro-enterprises affect innovation? Evidence from Pakistani handicraft micro-enterprises. Asian Business \& Management. https://doi.org/10.1057/s41291-019-00072-4.

Zahra, S. A., \& George, G. (2002). Absorptive capacity: A review, reconceptualization, and extension. Academy of Management Review, 27(2), 185-203.

Zahra, S. A., \& Nielsen, A. P. (2002). Sources of capabilities, integration and technology commercialization. Strategic Management Journal, 23(5), 377.

Zakrzewska-Bielawska, A. (2016). Perceived mutual impact of strategy and organizational structure: Findings from the high-technology enterprises. Journal of Management \& Organization, 22(05), $599-622$.

Zhang, H., Ou, A. Y., Tsui, A. S., \& Hui, W. (2017). CEO humility, narcissism and firm innovation: A paradox perspective on CEO traits. Leadership Quarterly, 28(5), 585-604.

Zhou, Y., Fan, X., \& Son, J. (2019). How and when matter: Exploring the interaction effects of high-performance work systems, employee participation, and human capital on organizational innovation. Human Resource Management, 58(3), 253-268.

Publisher's Note Springer Nature remains neutral with regard to jurisdictional claims in published maps and institutional affiliations. 